\title{
9
}

\section{The Rise of the Poverty-Stricken Millionaire: The Quest for the Good Life in Sargipalpara}

\section{Chris Gregory}

Bless me, $\mathrm{O}$ goddess Lakshmi, with children and grandchildren, stores of grain, elephants, horses, cows and chariots, good health and longevity,

Let illness, debt, poverty, evil, cowardice, sorrow, untimely death and the mental anguish that burns the mind forever be destroyed. (Vedic chant)

bap bera kansa tama, beta bera thenga-tuma.

Brass and copper at the time of father, but only a stick and a hollowed-out gourd at the time of son. (Halbi proverb)

\section{'Dwell in My House, O Lakshmi'}

The micro-economic history of the neighbourhood of Sargipalpara I present in this chapter can be read as a classic illustration of the ancient saying that 'as it is in the microcosm, so it is in the macrocosm (and vice versa)'. Just as Indian politicians and businessmen at the state and national levels in India have embraced the right-wing ideology of the Bharatiya Janata Party (BJP) on free market global capitalism and profited immensely from it, so too have local councillors and businessmen in the market town of Kondagaon and its neighbourhoods, such as Sargipalpara, 
enthusiastically welcomed the new economic order and successfully exploited the opportunities this has presented. This 'ant's-eye' perspective on the Bastar plateau-from its north-eastern corner-contradicts the popular 'bird's-eye' view of Bastar, which sees it as part of the 'red corridor' along the central spine of India said to be controlled by Maoist revolutionaries, the 'Naxalites'. Things always look different from the ground, and so it is for the residents of Sargipalpara for whom the north Bastar plateau presents itself as a 'parallel state' (Sundar, 2016) divided neatly between the hilly, drier, mainly millet-growing, Naxalite-controlled zone to the west, and the relatively flatter, wetter, mainly rice-growing areas in the BJP-controlled zone to the east. Kondagaon is the centre of a booming market economy in the east that stands in stark contrast to the Naxalite-controlled western zone, where many villages still have no electricity and where the Naxalites deliberately keep roads in a state of disrepair to make it hard for the government's counterinsurgency forces to pursue them. To the extent that trends in voting patterns are a measure of the quest for the good life, then the people of Sargipalpara are enthusiastic participants in a brave new world championed by the BJP. The local councillors of Sargipalpara sing the praises of the BJP with a fervour that borders on the religious as they point to the new houses, new cars and new motorbikes that now populate their neighbourhood.

The changes in material wealth have indeed been dramatic. The rapid commercial growth of Kondagaon has absorbed former small farming hamlets like Sargipalpara into its orbit and transformed them into city suburbs. The rapidly growing population of Kondagaon, fed by high local birthrates and rural-urban and interstate migration into Bastar, has sent urban land prices booming. Sargipalpara is now a desirable address for the emerging elite, whose new two- and three-storey mansions present a striking contrast to the mudbrick, thatched huts of the indigenous inhabitants, a few of whom have been able to imitate this rise, to varying degrees of success, with flash houses of their own. The new prosperity in north Bastar, then, has introduced new forms of inequality, one quite spectacularly evident in the modern mansion standing beside its traditional mudbrick neighbour. This phenomenon can be found all over India, and the world at large. Perhaps the world's most stunning example is to be found in Mumbai, where Mukesh Ambami, India's richest man and recent entrant into Forbes's list of top 10 billionaires, built the world's most expensive house in the world after Buckingham Palace, a 27-storey 
skyscraper requiring 600 servants to maintain it. Sargipalpara is not Mumbai; however, the changing skylines and recent history of both places have been shaped by the same dominant global values, the unequal economic consequences of which are quite literally there for all to see.

While extreme economic inequality presents itself materially as a visual contrast of the most obvious kind, other economic consequences are less visible. One such example is the paradoxical rise of what I call the 'povertystricken millionaire' - the poor, urban householder who suddenly finds that their previously worthless residential land is now worth millions. The rise of this paradoxical new economic class cautions against any simple-minded approach to understanding the growing inequalities in the world today and poses questions about the values that inform the thoughts and actions of this new class. At state are notions of wealth and competing conceptions of it - that of the global political economy and, conversely, of the domestic moral economy of Sargipalpara.

Piketty's (2014) bestseller gets to the heart of the matter from a global political-economy perspective. He showed that the composition of wealth in market value terms has changed dramatically over the past three hundred years. Data on the metamorphosis of capital in France over the period 1700-2010, for example, shows that agricultural land constituted about 60 per cent of all wealth in 1700 but fell to less than 1 per cent by 1970 . By contrast, the share of capital wealth in the form of urbanhousing land maintained the same relative value (about 15 per cent) from 1700-1970, but then rose rapidly to account for some 60 per cent of all capital in 2010. In other words, France was transformed from an agrarian capitalist economy to an industrial economy, and then to one in which urban-residential land is now the dominant form of wealth, an artefact of the rapidly rising relative price of urban land fuelled by the boom in the financial sector that followed the era of deregulation that began when Nixon floated the dollar in August 1971. India's economic history over the past 300 years has been very different; however, the same market forces have created the same patterns in the relative prices of rural and urban land over the past three decades. The phenomenon of the 'landrich, dirt-poor' householder has emerged everywhere, but the domestic values that inform their quest for the good life are everywhere different because familial values and religious values are everywhere different. 
The indigenous Halbi-speaking residents of Sargipalpara have a concept of wealth that is much broader than the narrow political-economy perspective in which the exchange value of commodities is deemed to be the only value that matters. This indigenous conception of wealth is elaborated in a 31,000-line oral epic about the goddess Lakshmi sung at rice-harvest time by women priestesses called gurumai. Lakshmi is the allIndia goddess of wealth and prosperity and, as the popular iconography illustrates, she is always associated with material wealth of some kind, be it grain, gold, cattle or the merchant's ledgers. She is also associated with water, elephants and lotuses. It suffices to note that these objects symbolise wealth of a 'spiritual' form. As the words of the epic make very clear, the spiritual values are very much of a this-worldly human kind. Lakshmi-who is rice personified in Bastar-brings wealth and happiness to those with whom she dwells. The ritual focus is on persuading Lakshmi to dwell in one's house today rather than living in nirvana tomorrow. Lakshmi is a fickle goddess who takes offence at bad conduct and leaves as soon as this happens. When she goes, her elder sister Alakshmi, the goddess of poverty and misery, takes her place. At harvest time every year, rice in the form of Lakshmi is ritually harvested and wedded to Narayan. During her journey from the rice field to the wedding venue she passes through the streets of Sargipalpara, stopping at houses along the way so that female household heads can ritually invite her to enter. The epic myth, and its ritual enactment, is an explication of the values of a domestic moral economy of a kind that makes no distinction between the realms of kinship, economy and religion. The 31,000 lines of the epic can be seen as an elaborate allegorical development of the two lines from the Vedic chant above, which capture the essence of the idea of the two notions of wealth involved: the objective material form and the human form. Material wealth includes domestic wealth in the form of food, clothing and shelter; productive wealth in the form of servants, seed, cattle, horses and elephants; and mercantile wealth in the form of gold, money, credit and the like. By contrast, human wealth includes familial wealth in the form progeny and harmonious relations with kin; social wealth in the form of fame, friends and social acceptance; and personal wealth in the form of good health and longevity.

Like all allegories, the epic tale admits of multiple interpretations, but the basic values as expressed in this particular version of the tale are clear and reflect the gender and cultural status of the singers. Lakshmi, an egalitarian goddess, is only concerned with right conduct and will dwell with anyone, 
whatever their caste. It is interesting to note that the egalitarian values that pervade the epic are of a social and cultural kind rather than an economic kind. Indeed, the epic notes the fact that some people are 'haves' and others are 'have-nots', but makes no moral judgement about it. A discussion of the values that underpin the epic is beyond the scope of this essay; suffice to say that it articulates what Ramanujan (1991) called a 'counter system' because it gives 'an alternative set of values and attitudes, theories of action other than the official one' (p. 33). The epic is unusual in that it is not a story of war and conquest. Nobody is killed. The only violence is domestic violence, when Narayan beats his newly wed wife Lakshmi. While I am yet to meet anyone in Sargipalpara who would not prefer more money to less, it is domestic-political relations within households and between households that primarily concern most people, especially women. This is a 'kinship-intensive' world where second and third cousins live cheek by jowl and where cross-cousin marriage has resulted in people being related in multiple ways. Human wealth, in the senses outlined above, is a central concern. The Maoist insurgency movement is, for the most part, something remote happening in the hills in the rural areas to the west; it is not part of people's everyday urban lives in Sargipalpara. The trans-cultural moral values the epic articulates give people food for thought as they practise the difficult art of trying to live together well in a world where history is forever throwing up new dilemmas and paradoxes, the emergence of the poverty-stricken millionaire being the latest.

In the micro-economic history of Sargipalpara that follows-one that reflects my 30 years of familiarity with the place-I illustrate, in general terms, how the paradox of the poverty-stricken millionaire has arisen and discuss, in more particular terms, how the indigenous subalterns manage their quest for the good life in terms of local conceptions of material and human wealth. I end with a case study of one poverty-stricken millionaire's quest for the good life. In my struggle to comprehend the mass of confusing data I have collected over the years, I am guided by Mauss's (2007) sage advice:

Note the differences between moral environments; court morality and popular morality. Women's morality is not men's; the morality of the old is not the morality of the young, and sexual morality is not general morality'. (pp. 156-57) 


\section{The Emergence of the New Elite of Kondagaon}

In the early 1900s, Kondagaon was a small farming village beside a creek next to the main road south to Jagdalpur, the capital of the then Princely State of Bastar in east-central India. Its residents grew rice, millet and vegetables, which they traded for other commodities in the Sunday market; some earned a few extra rupees by selling chai, snacks and other products to the passing traffic. Sargipalpara, another farming village, lay a couple of kilometres upstream and about half a kilometre back from the main road.

When I arrived in Kondagaon in 1982 to commence fieldwork on the periodic marketing system, it was a small market town with a population of 17,279 people, some 25 per cent of whom were relatively recent migrants; its Sunday market was the local regional centre of a large network of periodic markets on the north Bastar plateau; and its roadside shops and houses were spread ribbon-like two kilometres up and down National Highway 30. My wife and I found a place to stay in Sargipalpara, a neighbourhood ward of the expanding town of Kondagaon, the administrative centre of a regional district of the same name. Our house, a new, mudbrick, four-room dwelling with a tiled roof, was one of the first to be built in the neighbourhood on land that a Hindi-speaking migrant had purchased a few years before from a local Halbi-speaking farmer.

Between 1982 and 2006, I made 12 return visits to Kondagaon. Throughout this period the region remained, for the most part, a sleepy backwater where rice farmers eked out a precarious existence on rainfedirrigation paddy fields. It seemed as if the effects of the 1991 neoliberal economic policies that transformed the Gangetic plain and other parts of India were never going to be felt on the Bastar plateau. Therefore, I was shocked by the changes I observed in 2013 when I returned after an absence of seven years. The region, which has long attracted migrants from near and far within India because of its relatively abundant agricultural lands and its forests rich in game, minor forest products and timber of various useful kinds, was now attracting a new breed of immigrant. The mango trees along the main highway-those that had not been pulled out in the highway upgrade-advertised their arrival; competing agribusiness companies had covered the trunks of the trees with multicoloured foolscap-size cloth advertisements for new hybrid 
varieties of maize. The rice farms in the villages beside NH30 were flush with new maize crops irrigated by tube wells, the highway forming the main street of Kondagaon had been widened and commercial activity was flourishing as never before as the invisible hand of the neoliberal economic multiplier worked its magic.

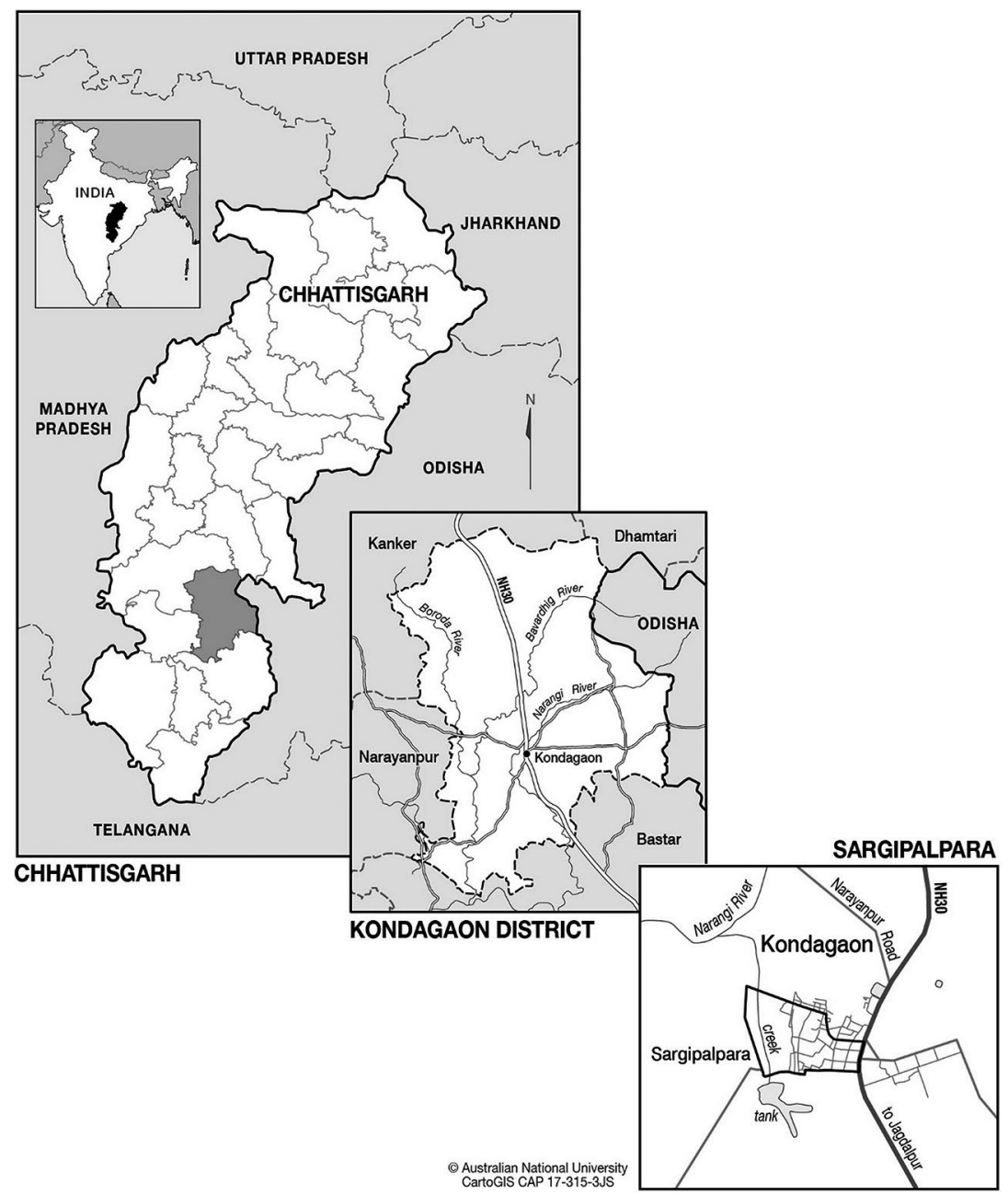

Figure 9.1: Map of Sargipalpara Ward, Kondagaon, India

Source: CartoGIS, College of Asia and the Pacific, The Australian National University.

The good life led by these new agents of change-mostly single men-is there for all to see. They dress in shirts with a logo that identifies their company; stay in Kondagaon's brand-new, air-conditioned, four-star 
hotel; work hard during the day competing with one another to strike new business deals; and relax in the evening with wine and whatever local women they are able to procure. These newcomers to Bastar, some of who bring their families and settle in the town, are the latest in a long line of migrants whose quest for the good life has brought them to Bastar. Some, the landless dirt-poor who scrounge a living working as domestic servants, day labourers and petty traders, have come from neighbouring states to escape rural poverty. Others, such as the mercantile elite from the Marwari-speaking region of Rajasthan, who began arriving in large numbers in the 1960s and 1970s, continue to prosper. The sons of migrants I studied in my 1980s research (Gregory, 1997) are shrewdly exploiting the new economic opportunities opening up; they claim their status as Kondagaon's cultural elite by building mansions in the now desirable residential area of Sargipalpara, marrying off their daughters to high-status families from their own caste from different parts of India and celebrating with expensive weddings fit for royalty. Yet, not all migrants have come for money. Some, such as the Hindu refugees from the Bangladesh Liberation War of 1971, were resettled in Bastar under a Government of India program; their quest for the good life has been a battle to re-create a moral community torn apart by the deadly violence of war. Then there are the Naxalites, the Maoist revolutionaries, whose quest for the good life stands in violent, polar opposition to the neoliberal entrepreneurs, whose conception of the good life is defined by the profits from the new hybrid seeds they are introducing and the natural resources, such as timber and iron ore, they are extracting.

When I first arrived in Bastar, the Naxalites were a distant rumble of unrest in the deep south; over the years they have slowly moved north and today inhabit the so-called red corridor that runs down the central spine of India. Their arrival, as the law of social physics would predict, has excited an equal and opposite counterinsurgency reaction. The north Bastar plateau is now a parallel state, where the land to the west of the north-south-running NH30 is ruled by the Naxalites and the region to the east by the ruling ultraconservative BJP. The border is marked at regular intervals by camps of counterinsurgency militia who, afraid of being shot, live like prisoners behind tall razor wire topped fences under the watchful eye of armed guards in towers. Kondagaon, like most towns and cities in Bastar, is very much under the control of the BJP Government. As such, everyday life in Kondagaon goes on as if the guerrilla war between these combatants does not exist, until an atrocity-such as the attack 
on a convoy of Indian National Congress leaders in the Darbha Valley in south Bastar on 25 May 2013, which killed 27 people-interrupts everyday life. I was in Kondagaon when this happened. The government declared a statewide curfew. All commercial and administrative activity ceased completely. An eerie silence followed that lasted 24 hours. Business as usual picked up again the next day as if nothing had happened. That, at least, is how things appeared; of course, what goes on behind the scenes is another matter, but that is something that people in Kondagaon never talk about-and do not want to talk about. Those locals who do talk about politics are enthusiastic supporters of the new economic order.

'You have been coming here for 30 years $d a d a$ ', a native Halbi-speaking BJP municipal councillor said to me in 2013. He continued:

You have seen the changes. We are rich now. We have nice houses, TV, sewing machines, beds, cupboards. Look at this pakka (modern) house we are standing in. Our chief minister is a great man. He has made us rich. Look at that sewing machine. He gave me one too. He has given many things away.

The councillor's monologue became more animated with every sentence. It was like a rousing political speech, and his fervour was contagious. 'Yes, yes', shouted two other men in the room, both of who were affines, or kinsmen, of the councillor: 'Raman Singhji, the Chief Minister, is a great man'. It is indeed true that the material conditions of many households in Sargipalpara have improved dramatically, but in a very uneven way. The pakka house that we were standing in was the only one belonging to a local in the immediate, crowded neighbourhood.

The past 100 years, then, has utterly transformed Kondagaon from a small, remote, roadside farming village into a rapidly growing, commercial and administrative centre that is now very much part of the Indian national polity and global economy, with all the social tensions that implies. Migration from all parts of India has turned it into a microcosmic exemplar of India's macrocosmic cultural diversity: while Hindi is the lingua franca, native speakers of Tamil, Telegu, Malayam, Bengali, Oriya, Marathi and every other major language of India, can be heard; while Hinduism is the dominant religion, the temples of its many and varied sects, as well as the mosques, churches and places of worship of every other religion in India can be seen; and hardly a week goes by in the annual cycle without the performance of the ritual of some religion somewhere in the town. Kondagaon's current (2011) population of 30,717 has members of all 
the major castes of India, but they live cheek by jowl in neighbourhoods whose rapid economic development has created a complex mixture of rich household and poor, high caste and low.

Ethnography is only possible when it takes a particular point of view; mine is that of the people who became my neighbours during my first field trip in 1982, members of the Halbi-speaking Ganda community, whose ancestors first settled in Sargipalpara an unknown number of generations ago, but certainly more than six. These people are members of the dirt-poor subaltern class of Kondagaon who have been both victims and patients of the rapid economic changes since the 1980s: victims in the sense that many are the landless sons and daughters of fathers who, in their selfish quest for the good life, sold their ancestral farmlands to outsiders to profit from the rapidly rising prices; patients in the sense that some are the passive recipients of new-found wealth as the owners of kacca (mudbrick) urban houses on land that (in 2014) is worth INR700 per square foot, a veritable fortune in a town where a kilogram of rice costs INR25. These are the poverty-stricken millionaires, the members of the new 'dirt-poor but land-rich' class.

\section{The Indigenous Subalterns of Sargipalpara}

The distinction between the elite and the subaltern is not a matter of academic debate in Sargipalpara. The starkness of the contrast is there for all to see as soon as one enters the neighbourhood. The elite live in large, newly constructed, brightly coloured, two-storey mansions surrounded by lush, well-watered gardens growing behind high walls and secure, elaborately designed, wrought-iron gates. By contrast, the subalterns live in small, old, tumble-down, white-washed, mudbrick, roadside shacks behind narrow, dusty pavements. This visual contrast is the outward and visible sign of an ever-widening gulf between the rich and poor in Kondagaon; underlying it are inward and invisible cultural values and social relationships whose form and colour can only be grasped by entering the houses and listening to the voices of the inhabitants. For these voices to make sense, it is necessary to zero in on the human geography of Sargipalpara, and to reconstruct the history of valuation of the four different categories of land that lie within its boundaries. 
The official census statistic is a useful starting point not just for its quantitative data but for the qualitative data provided in the official language used to classify the data. The latter is very important because it embodies the values used to inform government policy. The 2011 population of Sargipalpara of 2,062 people lived in 472 houses, an average of 4.36 per household. The household data are grouped firstly into castes and then into four official super categories called 'General' (G), 'Other Backward Castes' (OBC), 'Scheduled Castes' (SC) and 'Scheduled Tribe' (ST). The G category contained 109 households made up of Brahmans (30), Muslims (16), Thakur (16) and 47 households from a variety of other castes. The OBC category contained 141 households, with the Kosta (66) and Raut (21) being numerically dominant. The SC category contained 106 households, most of which belonged to the Ganda caste (87), while the ST category contained 116 households, 94 of which belonged to the Gond tribe. These official categories have important affirmative action implications for those so classified, which makes the tribe/caste distinction a hotly debated issue of identity politics in Bastar. To transcend the terms of debate these official government categories trap one in, it is necessary to subdivide caste data by language if we are to identify the subaltern and pose new questions for investigation.

Representatives of almost every major language group in India can be found in Sargipalpara; however, Halbi is the mother tongue of the original settlers of Sargipalpara and Hindi the lingua franca of everyone. If the data on official caste category is subdivided vertically by language- $-\mathrm{Halbi}$ speakers versus non-Halbi speakers-then we get the classification shown in Table 9.1, which can be read in two ways.

Table 9.1: Sargipalpara: Classification of Households by Official Caste and Unofficial Class

\begin{tabular}{|c|c|c|c|c|}
\hline Official classification & $\begin{array}{c}\text { Subalterns (mainly } \\
\text { Halbi speakers*) }\end{array}$ & $\begin{array}{l}\text { Elite (mainly non- } \\
\text { Halbi speakers } \wedge \text { ) }\end{array}$ & Total & $\%$ \\
\hline Official caste $(\mathrm{G}+\mathrm{OBC}+\mathrm{SC})$ & 231 & 125 & 356 & 75 \\
\hline Official tribe (ST) & 116 & - & 116 & 25 \\
\hline Total number of households & 347 & 125 & 472 & 100 \\
\hline$\%$ & 74 & 26 & 100 & \\
\hline
\end{tabular}

* This includes some speakers of other Bastar languages such as Gondi, Kosti, Bastari and Bhatri.

$\wedge$ These include speakers of 11 Indo-Aryan languages-Oriya, Marathi, Bengali, Awadhi, Bhojpuri, Gujarati, Marwari, Panjabi, Nepali, Sindhi and Chhattisgarhi-and three Dravidian languages - Telegu, Malayalam and Tamil.

Source: Fieldwork data. 
Reading down the rows gives the official picture of the social structure of Sargipalpara: 75 per cent of the population are officially classified as members of a 'caste' and 25 per cent as members of a 'tribe'. Reading across the columns gives us a different take on the official picture: 74 per cent of houses consist of Halbi speakers and the remaining 26 per cent non-Halbi speakers. The elite in Sargipalpara come almost exclusively from this latter group. The Halbi speakers constitute the bulk of the subalterns. The terms of the official debate defined by the distinction between 'tribes' and 'castes' poses the question of the cultural, political and economic status of the 25 per cent of households officially classified as ST. The terms of the debate defined by mother tongue pose the question of the cultural, political and economic status of the 75 per cent of households, the subalterns who live in kacca houses. It is the latter group I propose to investigate, but official data are of little help here. Their history is unwritten although recoverable by genealogical analysis and the collection of data on their oral traditions.

What unites these subaltern households vis-a-vis the elite is that they are the descendants of people who have been settled in Bastar for an unknown number of generations, but definitely more than six. Most of the elite, by contrast, have been in Bastar for two to three generations, but definitely not more than five generations. This, at least, is what the genealogies that I have collected reveal, an objective fact readily confirmed by the stories people tell. The sharp distinction, visually observable at the macro-level between elite and subaltern, becomes rather more complex as one zooms in on the multi-levelled divisions and subdivisions between the 347 subaltern households.

The first division is between those householders whose ancestors settled in Sargipalpara as farmers over four or five generations ago and those landless day labourers and petty traders who have recently arrived from neighbouring towns and villages on the Bastar plateau. The latter are the poorest of the poor. Many have come from villages where population growth and limited supplies of land have rendered them landless. They have been attracted to Kondagaon for the employment opportunities it provides and to Sargipalpara because relatives from whom they could seek assistance with accommodation and food live there.

The descendants of the original settlers constitute the bulk of the 'povertystricken millionaires' whose urban household plots have skyrocketed in value. These households are subdivided into two distinctive cultural subgroups based on relative wealth and caste status. The Kosta caste (66 houses) are the wealthiest. Their caste community (samaj) is the strongest and, in their 
own eyes and the eyes of many others in Sargipalpara, they are the most entrepreneurial. The superficial evidence for this is the number of pakka houses owned by members of this caste and the lavishness of the weddings they hold. On my last visit, in 2013, I attended a wedding of a daughter of a relatively wealthy Kosta man who has the largest pakka house owned by a Halbi speaker. The wedding was the talk of the town because he was the first Bastarian in Sargipalpara to include a car in his daughter's dowry. Many of his fellow caste members expressed great dismay about this because of the pressure its puts on them to follow suit.

\section{The Ganda (Weaver) Sub-Lineages}

The 83 houses of the less well-off and so-called lower status Ganda people are my central focus. This people also have their subdivisions, based on clan status and wealth, as Table 9.2 illustrates. The Korram clan, which consists of three sub-lineages comprising 48 households, is the only landowning clan. The other clans, consisting of some 35 households, have no farmland. The Baghel sub-lineages, as the village names of Sambalpur and Umgaon suggest, are relatively recent immigrants from these villages. They are the poor relatives but have many affinal links with the Korrams. They live together in a densely packed southern section of Sargipalpara the locals sometimes refer to as Baghelpara.

Table 9.2: Socioeconomic Differentiation of the Ganda (Weaver) Community of Sargipalpara

\begin{tabular}{|l|l|r|r|}
\hline Lineage & Location within Sargipalpara & $\begin{array}{c}\text { Households } \\
\text { (no.) }\end{array}$ & $\begin{array}{c}\text { Landholding } \\
\text { (acres) }\end{array}$ \\
\hline Original settlers & & 11 & 1.0 \\
\hline Korram I & Eastern section & 10 & 5.5 \\
\hline Korram II & Northern section & 27 & 9.0 \\
\hline Korram III & Western section & 48 & 15.5 \\
\hline Total & & & - \\
\hline Migrants & & 20 & - \\
\hline Baghel Sambalpur & Southern section & 5 & - \\
\hline Baghel Umgaon & Southern section & 10 & - \\
\hline Others & Southern section & 35 & 15.5 \\
\hline Total & & 83 & - \\
\hline Grand Total & & & \\
\hline
\end{tabular}

Source: Fieldwork data. 
The Korrams, then, are descendants of the original settlers, and settlement of the houses of the sub-lineages reveals the microhistorical geography of this part of Sargipalpara. Figure 9.2 shows the settlement patterns of the clans and sub-lineages of the Ganda community. It only covers part of the neighbourhood officially classified as Sargipalpara, and omits the 50 or so houses of the elite that are scattered around and between the Ganda houses. The households of the Korram I sub-lineage are coloured red and are clustered to the east; the households of the Korram II sub-lineage are coloured blue and clustered to the north; the households of the Korram III sub-lineage are coloured green and are clustered to the west; and the recent arrivals, the Baghels, are densely clustered to the south.

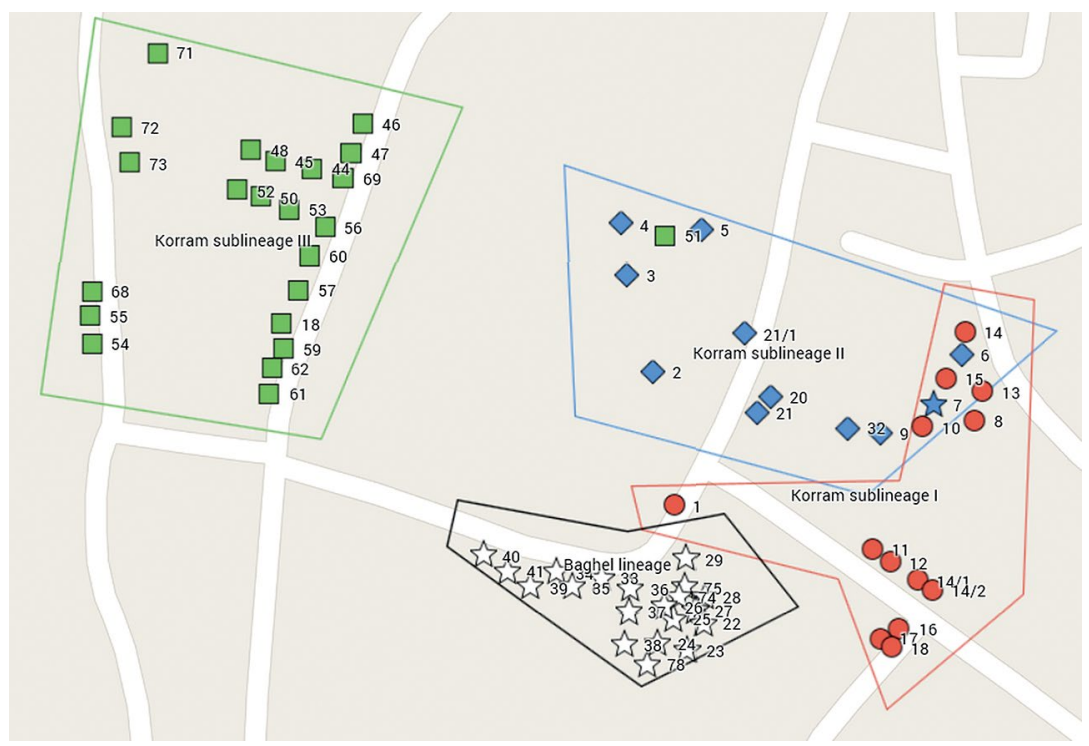

Figure 9.2: Map of Settlement Patterns of the Clans and Sub-Lineages of the Ganda Community of Sargipalpara

Source: Google Maps and fieldwork data.

The genealogical links between the three sub-lineages of the Korram clan have been forgotten, but kin within each sub-lineage are related as cousins to the third or fourth degree. My data show that some 17 per cent of marriages were internal to Sargipalpara, 59 per cent with Ganda spouses from neighbouring villages, and 24 per cent were inter-caste marriages, most of which involved Ganda women and immigrant men. Eighteen of the 83 Ganda households in 2011 were headed by women who were either widows or divorcees. 
Kinship relatedness, then, is very dense and all householders are integral parts of a very complex web of ever-changing relationships of consanguinity and affinity that bind people together. The patrilineal superstructures that unite households, although invisible to outsiders, are relatively stable, as they evolve slowly over time. Figure 9.3 shows the genealogical ties that bind the 10 households of the Korram II sub-lineage together.

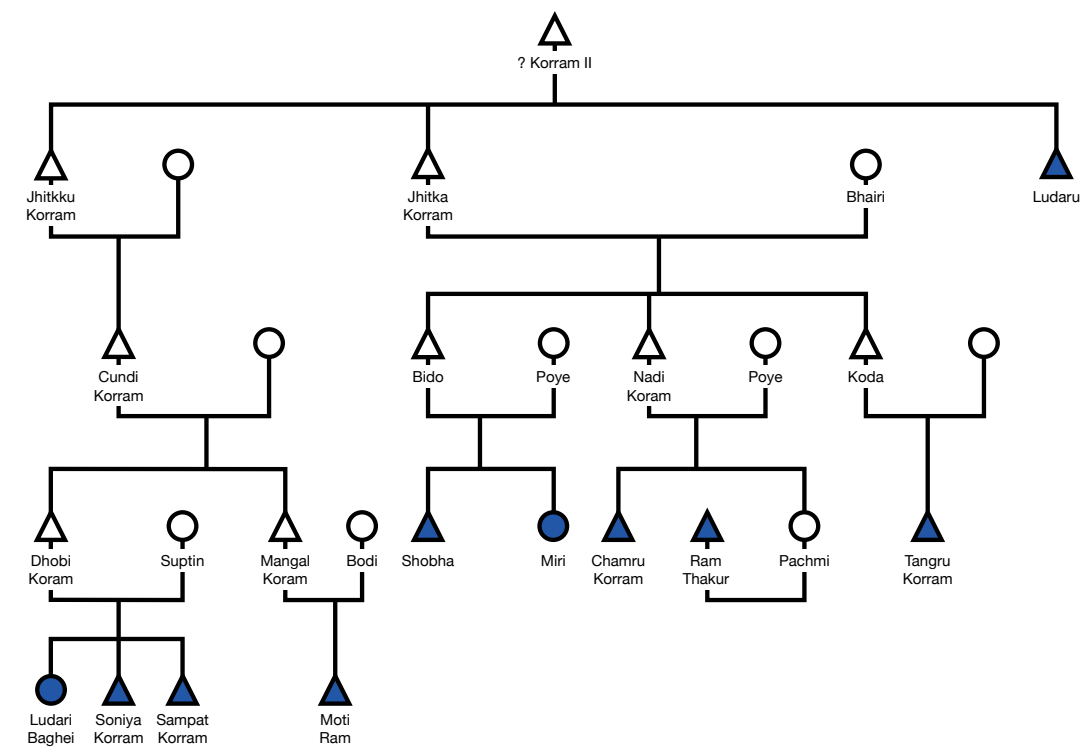

Figure 9.3: Genealogical Relationships Between the Households of the Korram II Sub-Lineage

Key: Triangle = male; circle = female; horizontal link below = marriage; horizontal link above = siblings; vertical link $=$ descent.

Source: Fieldwork data.

Of particular interest is household number 20 (H20), which is known as 'Chamru's household', even though Chamru died in 1999. This household is exceptional; however, it is precisely because of this that it can provide insights into the history of Sargipalpara as a whole. This household, which is the largest both in numbers of people and traditional landholdings, exemplifies the dirt-poor, land-rich paradox in Sargipalpara in its most extreme form. The origin of this paradox lies in the way the local agrarian economy of Sargipalpara has been turned upside down. It is necessary to briefly examine the history of this inversion. 


\section{Indigenous Conceptions of Land Classification and Valuation in Sargipalpara}

In the days when the residents of Sargipalpara were farmers, the value of land reflected its productivity as farmland. Land in Bastar is classified into four classes. At one extreme is the relatively highly productive, lowlying riverbed land on clayey loam called gabhar. This top-quality land is used exclusively for rice growing. At the other extreme is the relatively unproductive fourth-grade land called marhan, found on coarse sandy soil in the higher, wooded areas, suitable only for growing low-yielding, dry-grain crops like millet. These are the areas where farmers build their houses. Between these two extremes, Halbi speakers identify two intermediate categories: mal, second-grade, slightly higher land, suitable for growing rice but at a lower yield; and tikra, sloping, sandy, third-grade land best suited for millet.

Sargipalpara, whose boundaries are illustrated in Figure 9.1, contains all four categories of land. The creek travels through the low-lying lands to the west, the area where the best quality land lies. As one walks eastward towards Chamru's household, the elevation of the land slowly increases from a low of 580 metres at the creek bed to 600 metres (where the residential area begins), and the rice-yield ratio (kilos of rice harvested to kilos planted) falls gradually, from 30:1 on the top-quality gabhar land, to $20: 1$ on the second-grade mal land, and 10:1 on the third-grade tikra land. Relative land values have been directly correlated with these ratios on the relatively rare occasions when it has been sold (inheritance is the normal mode of transfer).

The commercial development of Kondagaon stimulated an active market in land. The top-quality gabhar farmland was still much sought after and its price rose rapidly in absolute terms over the years, but not as much as the fourth-grade upland marhan, which was in excess demand as urban household land. In 2015, gabhar sold for around INR130 per square foot while marhan sold for about seven times that amount, as Table 9.3 shows. Ganda householders have been active sellers in this market, which is why only 18 households of the 83 have any farmland left today. Twelve of the farmland-owning households have holdings of one acre or less, most of it of the second or third quality; the other six households, with holdings of 3 acres or less, again have holdings of mostly the lower quality type. Chamru's household still owns about 2.5 acres of farmland and was one of the largest owners of fourth-grade marhan land. However, as the 
urbanisation of Kondagaon turned this land into top-quality household land, much of this, too, has been sold. Two parts of the large plot on which the present house stands have recently been carved off and sold to buyers who have erected large pakka houses.

Table 9.3: Sargipalpara Land: Contemporary Market Values Versus Traditional Productive Values

\begin{tabular}{|l|l|c|c|}
\hline Halbi land classes & Use value of land & $\begin{array}{c}\text { Productive value } \\
\text { (rice seed to } \\
\text { yield ratio) }\end{array}$ & $\begin{array}{c}\text { Market value } \\
\text { (per square } \\
\text { foot in 2015) }\end{array}$ \\
\hline Gabhar & $>30: 1$ & $<$ Rs130 \\
\hline $\begin{array}{l}\text { Top-quality, low- } \\
\text { lying creek bed land } \\
\text { (580 metre elevation) }\end{array}$ & $\begin{array}{l}\text { High-yield, late } \\
\text { variety rice }\end{array}$ & $>$ >Rs700 \\
\hline Marhan & \multicolumn{1}{|c|}{} \\
\hline $\begin{array}{l}\text { Low-quality, higher } \\
\text { creek bank land } \\
\text { (600 metre elevation) }\end{array}$ & $\begin{array}{l}\text { Low-yield, early variety } \\
\text { rice; millet; housing }\end{array}$ & & $<$ \\
\hline
\end{tabular}

Source: Fieldwork data.

A close examination of the Google map of Sargipalpara reveals the presence of modern agri-business too. Farming in Bastar is, for the most part, based on rain-fed irrigation, but the dam that has been constructed has created the potential for a limited amount of irrigated farming of hybrid maize in the dry season. The six large, contiguous rectangular plots-something never seen in peasant farming systems because of the tendency of land to be divided and dispersed as it is inherited down a patriline-is owned by the new business elite. The visual division between elite and subaltern in the residential quarter is now being reproduced on the farmland.

The preceding discussion has revealed that life in Sargipalpara is simply complex. It is simple because economic changes have created a new and obvious stratification between the new elite and the original subalterns. It is complex because a household such as Chamru's is embedded in a multilayered domestic moral economy that opposes its members as land-rich, dirt-poor subaltern descendants of original settlers against recent arrivals who are dirt-poor; low-caste Ganda people originals against the higher status Kosta; members of the Korram clan against their affines in the recently settled Baghel clan; and members of the Korram II sub-lineage against other Korram sub-lineages. Chamru's household is a classic example of what Polanyi (1944, Chapter 4) describes as 'socially embedded'. The economic basis of their economy-peasant proprietorship in parcels of farmland of different quality — has, for the most part, gone, 
sold to high bidders. For them, the economy has become a superstructure whose workings they do not understand, but whose power they feel; it has dealt them a bittersweet blow by turning them into poverty-stricken millionaires. This has provided opportunities for some members of the household, misery for others, and difficulties for all because the complex, polyvalent, multilayered domestic moral economy in which they are socially embedded provides no simple answers to the moral dilemmas they face. The original subalterns of Sargipalpara live in precarious times, but it is a precarity shaped uniquely by the historical geography of the land they have settled on.

\section{The Story of One Poverty-Stricken Millionaire Householder's Quest for the Good Life}

We are now in a position to consider one poverty-stricken millionaire householder's quest for the good life in Sargipalpara. Given the complexity of the sociocultural and economic structure of the domestic moral economy in Kondagaon, it is useful to recapitulate the argument about the socioeconomic embeddedness of the household before delving into even greater complexity. Chamru's household is one of 10 households of lineage II of the Korram clan, the original landowning settlers who stand opposed, as members of the Ganda (weaver) community, to other landless members of the Ganda caste who have migrated to Sargipalpara from neighbouring villages over the past generation or so. The 83 houses that belong to the Ganda caste are part of the 347 houses that constitute the subaltern class of Sargipalpara. The 264 'other castes' category includes about 66 households of the Kosta (silk weaver) caste who, like the Ganda, were original settlers; the rest are, for the most part, landless migrants from nearby villagers. In other words, around 30-35 per cent of subaltern houses are in the 'land-rich, dirt-poor' category. Considered a class, this group is betwixt and between the dirt-poor group and the relatively rich, elite group that numbers some 125 households.

Figure 9.4 captures the embeddedness of Chamru's household; it is clear that as one moves up the hierarchy, the values that govern relationships between the houses change from the domestic and familial to the national and political, in which class becomes an issue. Economic and religious values permeate every level, but the links between the religious and the familial come to the fore as one moves into the household level. The domestic moral politics of Chamru's household illustrate this. 


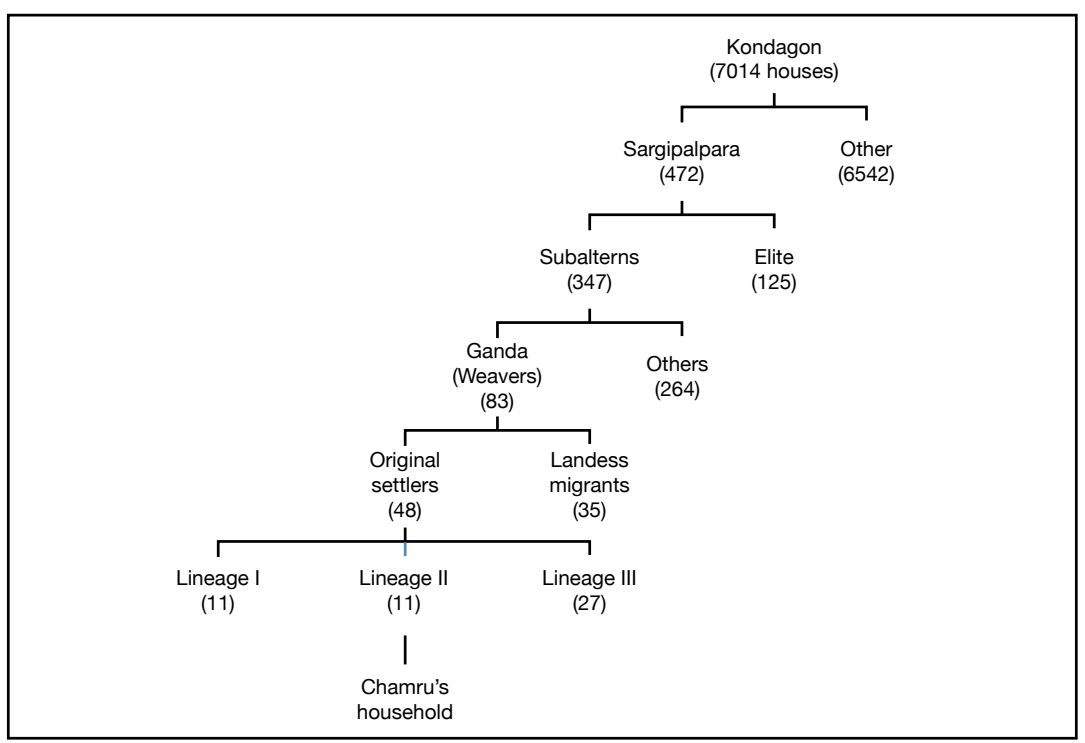

Figure 9.4: The Social Embeddedness of Chamru's Household

Source: Fieldwork data.

Figure 9.5 shows the structure of Chamru's household, H20, as it was in 2013. This household, now headed by Chamru's widow and fifth wife, is exceptional for a number of reasons. First, numbering 21 people, it is the largest household in Sargipalpara by far, given that the average size is around five people per household. Second, Chamru had seven surviving daughters, a son by his fifth wife and a son by his third wife. Three of these daughters have in-marrying husbands and children living in the house. In-marrying husbands are called lamsena in Halbi; they are the butt of jokes because tradition demands that wives move to their husband's places after their wedding. The lamsena arrangement is classically resorted to when the parents of the groom cannot afford to pay for the wedding. The betrothed boy moves into his bride-to-be's household as a servant on the understanding that the cost of the eventual wedding will be paid for by the bride's father. Third, the household is located on a relatively large 15,600 square foot urban plot that had a market value in 2015 of INR11,000,000 (USD175,000), a fortune by local standards. This household, then, is a wealthy joint family but one that does not fit the classic model of the Indian joint family united by a male head, his sons and their wives. Like all joint families, this one will inevitably divide; how it does so remains to be seen. Nevertheless, we can gain some insight into the values that will inform people by examining the history of the family, focusing on Chamru's quest for the good life and on its consequences. 


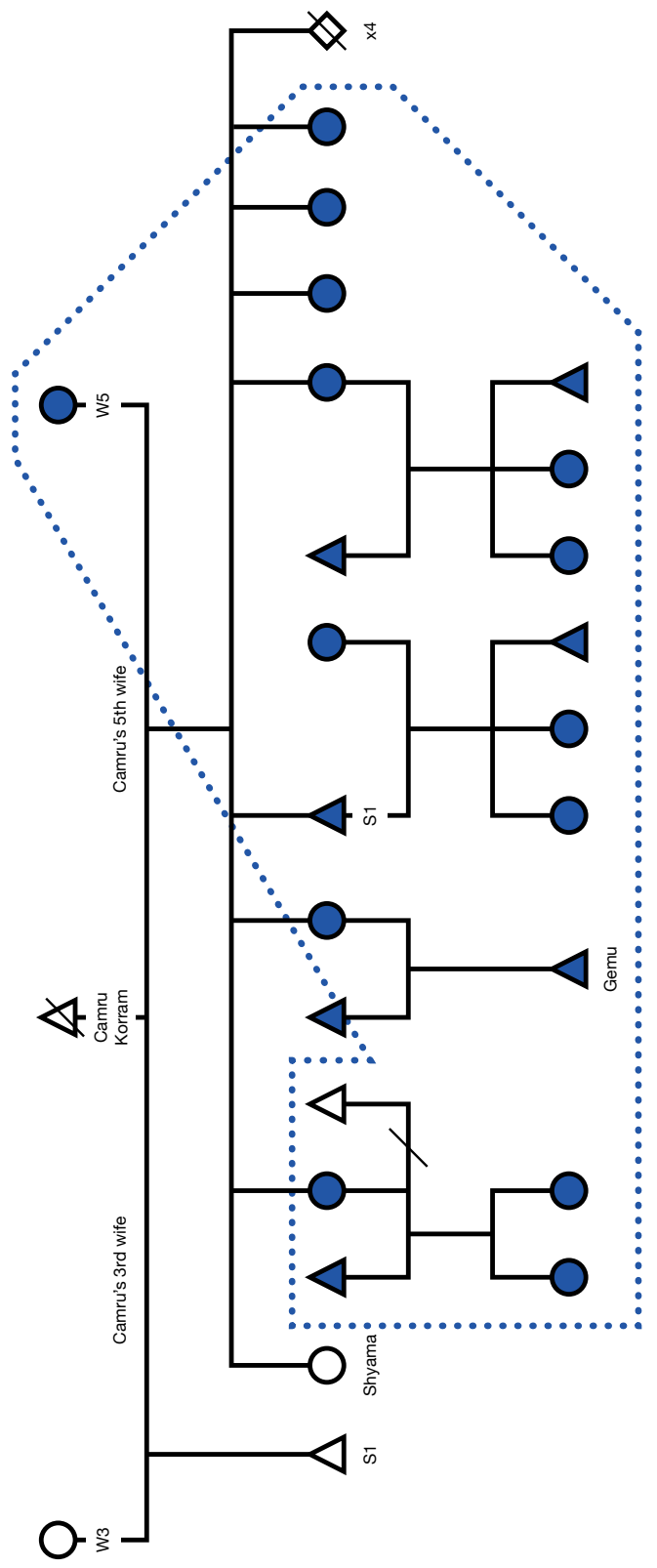

Figure 9.5: The Kinship Relationship Between Members of Chamru's Household

Key: Triangle $=$ male; circle $=$ female; horizontal link below $=$ marriage; horizontal link above = siblings; vertical link $=$ descent; slash $=$ deceased or divorced .

Source: Fieldwork data. 
To the extent that wealth is measured in terms of progeny and familial respect, Chamru has been an undoubted success. Not only has he produced nine surviving children, but he continues to live on in the memory of his kinsfolk as a respected duma - an ancestral spirit who possesses mediums and who is consulted for advice on domestic-political matters. For women like Gurumai Sukdai, a respected singer of the Lakshmi Jagar epic and mother of three daughters, progeny is the most important form of wealth. Nay more, the fact that Chamru had seven daughters is his most important achievement, for girls are, as the epic she sings makes clear, the embodiment of Lakshmi and of the auspiciousness she personifies. However, to the extent that wealth is measured by personal wealth (in the sense of a long and healthy life), social wealth (in the sense of fame) and material wealth (in the sense of an abundance of possessions), then Chamru's career has been much more chequered. He achieved great fame and fortune twice, but squandered it twice and died relatively young. Gurumai Sukdai gave me a long and detailed account of his life. In the following paragraphs I give a potted summary of her account along with the occasional quote.

As the descendant of an original settler to Sargipalpara, Chamru inherited farmland, weaving as a hereditary caste occupation and a religious specialists' role as spirit medium (siraha). By the time Chamru reached manhood, machine-produced cloth had long destroyed the hand-loom trade in Sargipalpara; however, he was able to successfully exploit the economic opportunities that his landholdings and his renown as a spirit medium presented. He was fortunate enough to be part of a patriline that produced four sons in his father's generation, but only two males in his own generation. As such, he inherited a relatively large portfolio of land of different qualities, including a substantial amount of the low-quality marhan, whose subsequent market value as residential land was to soar. Chamru never went to school but was a successful farmer who, through hard work and careful marriages, managed to increase his landholdings.

The steady growth of Kondagaon brought with it migrants from neighbouring states, many of them single men looking for wives and for business opportunities. One of these migrants persuaded Chamru to give him his sister in marriage and to go into business with him making bricks at Bailadila in south Bastar, where the establishment of an iron ore mine provided opportunities for a quick profit. Chamru mortgaged his farmland, pawned his wife's jewellery and headed off to Bailadila. As Gurumai put it: 
In this way his by now extensive landholdings passed from his direct control but he retained ownership. They had so much rice the eyes could not see it all. They had lots of land and lots of grain but in those days the price of farmland was very low. They had workers but their earning fell as a result of this and they were in big trouble. Such was his greed to make money on the brick contract that he did not save anything, not a single grain of rice. He lost everything. There was much wealth in his father's time but now there was nothing. We say bap bera kansa tama, beta bera thenga-tuma, which translates as 'brass and copper at the time of father, but only a stick and a hollowed-out gourd at the time of son'. His life was like that.

By this time, Chamru had married his fifth wife, who produced 13 children, only nine of whom survived. They lived in great poverty and suffered a lot. According to Gurumai, their fortunes began to change after his wife decided to plant a tulsi shrub and to host a performance of the Lakshmi Jagar epic. Such performances involve the singing and ritual enactment of the 31,000 lines of the oral epic. This must be done at harvest-season time every year for three years; it lasts for nine days in the first year; 11 days in the second year; 13 days in the final year; and always finishes on a Thursday, called Lachimbar (Lakshmi's Day) in Halbi.

A crucial factor in the family's economic turnaround was Chamru's growing fame as a spirit medium. His spiritual ancestor possessed him when he was a teenager. His grandfather had great renown as a spirit medium and apocryphal tales had long circulated of his grandfather's miraculous powers. He died relatively young and his duties were taken over, first by Chamru's father and then his father's brother, both of whom also died relatively young. Chamru was only a teenager when his powers as a medium were revealed; however, it was only after he returned from Bailadila that he began to be consulted on a regular basis. This was not entered into as a business, although his growing fame as a medium had accidental material side benefits. As Gurumai Sukdai noted:

There was an altar at Chamru's house. People from faraway would come to be cured. Chamru was highly respected and lots of worshipping (рuja) and religious activity happened in his house. People would come on Tuesday and Saturday to consult the spirit (dev) who possessed him. People were grateful for getting cured and as a sign of appreciation they would leave a gift. He was regarded as a very trusted spirit. 
This accidental wealth enabled him to free his mortgaged land and to begin again as a farmer. His growing family, previously a hindrance because they represented mouths to feed, now became an asset through the labour they performed in the house and on the farm:

As the children grew up they worked here earning money washing pots and doing housework. A Hindi-speaking outsider named Kori moved into the house, taking Chamru's eldest daughter as his wife. He helped Chamru free his mortgaged land and repaired his house. The family became very wealthy, even more so than many of his neighbours from the Kosta community. The family employed workers on their farmland and wealth in the form of brass and copper pots and pans. They had lots of money, many good rice plots and a large household plot. But Chamru became greedy and lost it all. All that remained was his house. He lost everything because his deity ceased to possess him because of his drunkenness and greed. He began to practise witchcraft on his patients. He would tell people that he was curing them but he was actually practising witchcraft. When people suspected this, they became frightened and stopped coming. He was a physically fit man but he died in the prime of his life. They performed his mortuary ritual and his eldest son Hari, from his second wife, shaved his head and performed the duties of chief mourner. The deity did not possess anybody else after his death.

Chamru's rise and fall as a spirit medium is a classic illustration of the fickle nature of fame. The gossip and rumour that circulates about someone's outstanding power and elevates them above the rest of the pack is the very same gossip and rumour that brings them undone when something happens to lead people to question the assumptions they hold about the person in question. It matters not whether the assumption is true or false; it is the fact of the assumption that matters. The rumour that he was practising witchcraft, which was no doubt fuelled by his alleged drunken behaviour, spread and brought him down. Such is the morality of the domestic moral economy; when the court of public opinion judges someone's behaviour as immoral the consequences can be very serious. This informal system of public morality, which is neighbourhood- and community-based, sits alongside two formal, more narrowly caste-based systems of morality and social control. The first is grounded in local religious beliefs and practices and centres around the ancestral spirits (duma) and the mediums (siraha) they possess. In this sense, Chamru, as ancestral spirit, continues to play a role in the social life of the living. Gurumai's account of his apotheosis is as follows: 
Chamru's younger brother Shobha had two sons. The youngest, Lachman, was miraculously cured of a severe disability after he was possessed by Chamru's spirit (duma) and became a siraha. Lachman was fit and healthy as a child but as he grew up his body became deformed. He stopped wearing clothes. He was naked like a cow. He couldn't stand to have clothes on his body. He was unable to walk and even unable to wash his body after defecation. His mother had to do this for him. He would just wrap himself in a shawl and sit. When Chamru died the community performed a sacrifice ritual called jatra. This went on for four days. Sirahas from many villages were invited. After three to four days they performed the dev bharto ritual to see if anyone from Chamru's clan would become possessed. To everyone's surprise Chamru's deity possessed Lachman and he stood up straight. He was cured of his disability and he returned to normal life. He got married and is now the father of a son. Lachman is now a renowned siraha who is possessed by many different spirits. It takes more than five men to hold Lachman when he is possessed by a very powerful female deity like Kankalinmata. Another is Telanginmata. When this female deity possesses him, she makes a hole in his tongue, dresses up in female clothes (nath, choli and lahanga) fastens bells to her feet, puts a red mark on her forehead and dances vigorously. Other deities who possess him include Gouriyamata and Butiyadev. Ancestral spirits (duma) of dead siraha possess him too. These include Chamru's spirit as well as those of Chamru's father and Chamru's father's brother. Another is Curlin, a deity who flies through the air, enters the body of pregnant women, and causes them delivery problems that kill them during childbirth. When this dev comes nobody stays nearby because she tickles him or her and kills them. Another great female deity of Bastar who possesses him, is Mata Mawli. Sirahas in this lineage all die in the prime of their life.

The second form of male social control is of a more secular kind. The final stage of Gurumai's story tells of Chamru's son's succession to his father's role as both medium and caste leader (naik).

Now the deity possesses Chamru's eldest son, who is also the naik. Ganda people from many villages gathered and installed Chamru's eldest son Hari as their caste leader (naik). They arranged for the musicians and sacrificed two goats. They appointed Hari as naik and Nandlal as paik. The $n a i k$ and paik are always from the same clan and the job of the paik is to assist the naik. They are selected on the basis of their ability to do the job and, upon the death of a leader, a younger brother or family member of the deceased will be selected if they are deemed suitable. Whenever a caste meeting (samaj) is to be held the paik goes to the house of every member and informs them about the date, day and time of meeting. The job of the naik is to arrange for the reintegration of outcasts. For example, if the 
gods have caused problems for someone, or if someone hits someone else with a shoe-be it in a domestic argument between husband and wife or some other fight- then the naik must arrange for their purification and reintegration. He brings water from Bare Dongar [the former capital of Bastar in precolonial times] and stores it in his house. He arranges for the caste community (samaj) to gather, sits the affected person down, and sprinkles them with the holy water. From then on, the affected person may mix with other members of their caste, who will now accept water from the hand of the previously outcast person. A deity possesses Hari so that, like his father Chamru, he is both naik and siraha.

Chamru may not have achieved lasting wealth and fame when judged at the neighbourhood and community level, but at the lower level domestic moral economy of Sargipalpara's three Korram clan lineages, his life was a very successful one. He acquired wealth in the form of progeny and fame, both as caste leader and medium. The rising price of urban land in Sargipalpara has given the household new-found wealth for the third time. Chamru only fails on the score of a long life, but that seems to be the price one has to pay to be a respected medium in Sargipalpara. Chamru's son now takes on this dubious status. He also assumes the mantle as poverty-stricken millionaire, but whereas his father built up the large joint family that now occupies $\mathrm{H} 20$, his son will have to negotiate its division and dissolution.

\section{Conclusion}

The preceding account of the recent micro-economic history of Sargipalpara has focused on the objective economic facts of land prices and class and one woman's perspective on the life of a man of renown. My interlocutor, Gurumai Sukdai, as the singer of two oral epics, is a woman of renown herself. I have collected her autobiography and her biography as told by her youngest daughter, Babita. I finish with a very brief extract from the latter to illustrate Mauss's point that a woman's morality is not that of men's:

Mum learned to be become a gurumai from my father's mother. Before that she used to go to make bricks. She used to make clay roof tiles. She used to sell rice and she also used to travel to the periodic markets. She also knows how to lay bricks with a builder. She did all these different jobs and raised her children. She also made bricks and built a house. She ate rice in one break and gruel in another and built a big house. 
Her middle daughter used to go to work with mum and helped her. The youngest one [the narrator] went to school. She studied until seventh grade. After this she left school and, under her own volition, went to a temple and got married. Before the marriage her husband did not drink. Later on, he learnt to drink. He also learnt to how to gamble. Hanging about with his friends, he learned every bad habit and forgot about home. Forgetting about home made it very difficult [for the narrator] to clothe and feed the family. The children, too, feel very sad. When working, he works like a bull, but he doesn't know to eat. Even when explained he does not understand. After mum and my sisters saw my condition they were sad and they brought food, soap, oil and clothes for me. Of the three sisters, the greatest sadness and misfortune has befallen me. My fate is the worst of all. Their destiny was to find a good husband. My destiny was to find a bad husband. The way my husband lives has made my life like that of a widow.

Sadly, Babita did not become a widow. Unlike the goddess Lakshmi, who merely gets beaten-up by her husband, her husband murdered her in a drunken rage, and it was left to her elderly mother to raise her four young children. Such events enable one to appreciate why the activities of the Naxalites and the BJP are a distant concern and why domestic morality is a principal cause of concern for women. The enemy lies within for these women in urban areas. For those lucky ones like Gurumai Sukdai who have a small urban plot, the values of the global political economy can be a blessing as well as a curse. Her household, while of the land-rich, dirtpoor kind, is not of the 'millionaire' variety like Chamru's. Nevertheless, she has exploited the opportunities the urbanisation of Sargipalpara has offered by dividing her house into three small apartments and renting two of them out.

\section{References}

Gregory, C. A. (1997). Savage money: The anthropology and politics of commodity exchange. London, England: Harwood. doi.org/10.4324/ 9780203986639

Mauss, M. (2007). Manual of ethnography. London, England: Berghahn.

Piketty, T. (2014). Capital in the twenty-first century. Cambridge, MA: Harvard University Press. doi.org/10.4159/9780674369542 
Polanyi, K. (1944). The great transformation: The political and economic origins of our time. New York, NY: Rinehart.

Ramanujan, A. K. (1991). Towards a counter-system: Woman's tales. In A. Appadurai, F. J. Korom \& M. A. Millls (Eds), Gender, genre, and power in South Asian expressive traditions (pp. 33-55). Philadelphia, PA: University of Pennsylvania Press.

Sundar, N. (2016). The burning forest: India's war in Bastar. New Delhi, India: Juggernaut Publication. 
This text is taken from The Quest for the Good Life in Precarious Times: Informal, Ethnographic Perspectives on the Domestic Moral Economy, edited by Chris Gregory and Jon Altman, published 2018 by ANU Press, The Australian National University, Canberra, Australia.

doi.org/10.22459/QGLPT.03.2018.09 